\title{
Durability studies of an indirect diesel engine run on raw palm kernel oil
}

\author{
*Godwin K. Ayetor, Joseph Parbey, Gabriel Osei
}

Koforidua Polytechnic, Faculty of engineering, Koforidua, Ghana

*kafuiayetor@yahoo.co.uk

\begin{abstract}
This works considered the possibility of using raw palm kernel oil as an alternative to petroleum diesel fuel in a VW engine. At present, very little results on engine durability tests of palm kernel oil use as a fuel has been recorded in literature. A Four-stroke indirect injection diesel engine with capacity of $314,280 \mathrm{x} 10^{3} \mathrm{~mm}^{3}$ and compression ratio 20.1:1 with constant water cooler was used for the investigation. The engine used for the experimentation is an indirect diesel engine, which is normally the type installed on agricultural engines. The engine was run alternatively for 100 hours on petroleum diesel and palm kernel oil respectively. After the durability test, sample of the lubricating oil was collected and sent for laboratory test. Viscosity, additives and metallic debris was analysed during the laboratory test for both fuel cases to determine wear. Visual inspection was also carried out to determine the state of the engine before and after each run. The engine run with petroleum diesel fuel was compared with that of the engine with palm kernel oil based on their fuel supply system and the lubricating oil analysis. The results showed that raw palm kernel oil can be used as a substitute to petroleum diesel in an indirect diesel engine without any significant damage. In terms wear, the vegetable oil even showed better performance due to its high lubricity compared with petroleum diesel fuel. It is recommended that a heating system be installed on the engine to run on palm kernel oil.
\end{abstract}

Keywords: palm kernel oil; raw vegetable oil; straight vegetable oil; durability; lubrication oil.

\section{Introduction}

Increasing industrialization has led to an upward surge in demand for petroleum products (Agarwal, 2007). The transportation and industrial sector account for $92 \%$ of global liquid fuels demand in 2040 as economies move from a subsistence to an industrial or service base economy (IEO, 2014). Economic development causes growth in the industrial sector which entails transport of goods for manufacture and manufactured goods after manufacture. By 2030 about half of the increase in global energy demand will be for power generation. The demand for petroleum is predicted to surge speedily in the transport sector over the next 25 year (IEO, 2007). Up to $80 \%$ prime energy expended in the world is fossil fuels of which $58 \%$ is used for transport (Escobar et al., 2009). It has been estimated that oil production will show a downward trend to become just 35\% of today's production by the year
2075 (Aliyu et al., 2011). From 2000 through 2008, petrodiesel consumption increased by $23 \%$, other petroleum products consumption grew by $7 \%$ (IEO, 2007).

In order not to incur much more costs, use of plant oils with automotive engines with little or no modifications have been suggested. Especially, since the use of plant oils as automotive fuel will lead to more than $80 \%$ reduction in exhaust emissions. However, current study has focussed on biodiesel (refined vegetable oil) at the expense of raw vegetable oil. This has been primarily due to the high viscosity of plant oils which have the tendencies of causing injector coking, incomplete combustion, pump failure and piston ring sticking (Hellier et al., 2015). Biodiesel is a refined form of plant oil and it is defined as fuel made up of mono-alkyl esters of long chain fatty acids obtained from plant oils or animal fats through a process called transesterification. It is designated B100 and must meet the requirements of 
ASTM D6751. Biodiesel fuel compared with the raw vegetable oil fuel, has a much lower viscosity similar to petroleum diesel (Knothe et al., 2015). Unfortunately, the cost of transesterification adds to the cost of the fuel, making biodiesel more expensive. The technology is also not common to rural folks.

Raw vegetable oil such as palm kernel oil, palm oil, Jatropha oil and coconut oil can be easily made anywhere in the world. It will be a great relief, if rural communities including farmers are able to fuel the farm machines with raw vegetable oil extracted from plant oils grown aside their food plants. Accessibility, availability and transport of fuel will no longer be an issue. This has the potential to increase employment in the rural area and even increase governments drive for rural electrification.

Though not many, some engine runs have been carried out to determine the possibility of using raw vegetable oils as fuel alternative to petroleum diesel. This works looks at the possibility of using raw palm kernel oil as an alternative diesel fuel in a VW, fourcylinder, four-stroke, indirect injection engine which is turbocharged and air cooled. Studies on engine durability tests of palm kernel oil use as a fuel are limited. The engine used for the experimentation is an indirect diesel engine, which is normally the type installed on agricultural engines.

\subsection{Durability analysis}

The diesel engine originally was built for use with raw peanut oil as fuel by the inventor Dr Rudolph Diesel. That is because peanut oil, also plant oil, has similar properties as petroleum diesel and can work in a compression ignition engine. Cetane number, which determines ability of the fuel to self-ignite is quite close. Unlike spark ignition engines, a diesel fuel is expected to have self-lubricating properties measured in terms of lubricity. The lubricity of vegetable oil for instance has been found to be better than petroleum diesel (Hazrat et al., Khan, 2015). Except that vegetable oil in itself is hygroscopic, capable of absorbing water, and causing wear in machine parts. It is therefore important that as part of the durability analysis, the wear pattern of the fuel is established to determine whether engine life will be lessened. Currently, there is no standard for raw vegetable oil use in an engine (Blin et al., 2013). Some have investigated vegetable oil engine use but fail to make wear analysis (Bohl, et al., 2014). Material compatibility studies were conducted for soy straight vegetable oil but straight palm kernel oil was never considered (Wander et al., 2011). Some also conducted durability studies but only considered engine runs for their blends with petroleum diesel (Gopal \& Raj, 2016).

Vegetable oil, unlike ethanol differs significantly in chemical structure depending on the source of feedstock used. Hossain and Davies (2010) did a comprehensive review on durability tests performed on vegetable oils of about a dozen feedstocks and their diesel blends. They found out that variation of feedstocks significantly affects results obtained. It is thus necessary that engine tests be conducted for an exact feedstock in order to determine its engine performance.

It has also been reported that engine type and ambient conditions do affect engine performance results (Mofijur et al., 2013). It will therefore not be appropriate to relate results of engine tests obtained in cold countries to that of sub-Saharan Africa since variation in ambient temperature alone could make the results void. Since the experimentation of this work was conducted in Ghana the results can very well relate to sub-Saharan African countries which have similar atmospheric temperature patterns.

\subsection{Lubrication oil}

Lubricant oil collects metal debris as a result of engine wear. Engine oil analysis is therefore one of the best methods of determining engine defects due to wear (Wander et al., 2011). The essence of lubrication oil is to lessen wear and also cause cooling. The lubrication oil is prepared such that there are a set of additives called additive pack in addition to the base oil. The additives are made up of wear inhibitors, detergents, dispersants and viscosity modifiers. The viscosity modifiers help to keep the viscosity of the oil stable since viscosity is essential for lubrication. The viscosity stability is necessary to enable the lubrication oil work over a wide range of temperatures since viscosity itself is influenced by temperature. The detergents in the additive pack are made up of sometimes calcium or magnesium. The detergents are needed to clean the engine during lubrication. The wear inhibitors such as Zinc Dithiophosphate helps prevent wear that occur due to metal-metal contact.

\section{Methodology \\ 2.1. Experimental set-up}

The experimental setup consists of an indirect injection diesel engine, stopwatch, digital tachometer, gas burner, palm kernel oil, petroleum diesel and injector test bench. The indirect injection diesel engine GT 2.8 TD used for the test was a four stroke 
four-cylinder turbocharged diesel engine. The specifications of the four stroke indirect injection diesel test engine are given in Table 1.

Table 1

Specification of test engine

\begin{tabular}{ll}
\hline Model/make & Golf 3 \\
\hline Engine type & Four stroke, water cooled, turbocharged diesel engine \\
Cylinder number & Four (4) \\
Combustion chamber & Indirect injection \\
Bore (mm) & 100 \\
Stroke (mm) & 100 \\
Compression ratio & $20: 1$ \\
Rated power & $51 \mathrm{~kW}$ at $2400 \mathrm{rpm}$ \\
Maximum torque & $215 \mathrm{Nm}$ at $1400 \mathrm{rpm}$ \\
Injection pressure bar & $215^{\circ}$ \\
\hline
\end{tabular}

\subsection{Experimental Procedure}

The experiment was conducted in two phases. In the first phase, the engine was run with petroleum diesel fuel for a total of 100 hours duration. Before running the engine with diesel fuel, the following method was carried out;

- The engine was serviced with fresh diesel engine oil (SAE15W 40), new oil filter and fuel filter.

- The injector test bench was used to test the injectors to determine its spraying pattern and also record the pressure bar.

- Cross-section of the fuel filter was viewed before running the test.

- The engine was then run for a total of 100 hours on petroleum diesel after servicing at a constant engine speed (1000 rpm). The process was repeated for raw palm kernel oil engine run after engine oil and fuel filter used for petroleum diesel had been replaced.

- A stopwatch was use to time the engine when performing the test.

- A digital tachometer was also used to determine the speed of the engine.

- After running the engine for 100 hours for petroleum diesel and palm kernel oil, the engine oil was taken for laboratory tests in each case. Viscosity, metallic debris and additives were analyzed in the lubricating oil.

After 100 hours of each fuel run, the engine was dismantled and the physical condition of various engine components was inspected carefully. Carbon deposits on various engine components and engine wear was inspected and photographed.

\section{Results and Discussion \\ 3.1. Physiochemical properties}

For a compression ignition engine the fuel viscosity is critical since it impacts the fuel injection components functions. The viscosity of raw palm kernel oil was recorded as $29.9 \mathrm{cSt}$, while that of petroleum diesel was recorded as $3.2 \mathrm{cSt}$ as shown in Table 2.

A fuel with higher cetane number will ignite at lower temperatures and have brief ignition delay. A higher cetane rating therefore gives a smaller ignition delay. However, extreme values of $\mathrm{CN}$ results in misfiring and cold starting (Innovam, 2007). The appropriate cetane range of diesel engines is between 40 and 60 . Cetane number of both fuels falls within the required standard. 
Table 2

Physiochemical properties of raw palm kernel oil and petroleum diesel

\begin{tabular}{lcc} 
& Raw palm kernel oil & Reference Diesel \\
\hline Viscosity @ $40^{\circ} \mathrm{C}(\mathrm{cSt})$ & 29.9 & 3.2 \\
Cetane Number & 60 & 45 \\
Heating Value $(\mathrm{MJ} / \mathrm{kg})$ & 39 & 48 \\
Density $\left(\mathrm{kg} / \mathrm{m}^{3}\right)$ & 914 & 862 \\
Flash point $\left({ }^{0} \mathrm{C}\right)$ & 312 & 90 \\
\hline
\end{tabular}

\subsection{Piston crown}

After 100 hours of engine run, Figure 1, shows an increase of particulate matter on the piston surfaces of engine run on palm kernel oil. This is as a result of incomplete combustion. Relative to reference diesel, the particulate matter of palm kernel oil was found higher. This is because of the higher viscosity of the palm kernel oil. Higher viscosities lead to reducing in-cylinder temperatures which reduces fuel atomization efficiency creating fuel rich zones which is one of the cause of incomplete combustion (Hellier et al., 2015). There will be a need to retard the injection timing to arrest this situation.

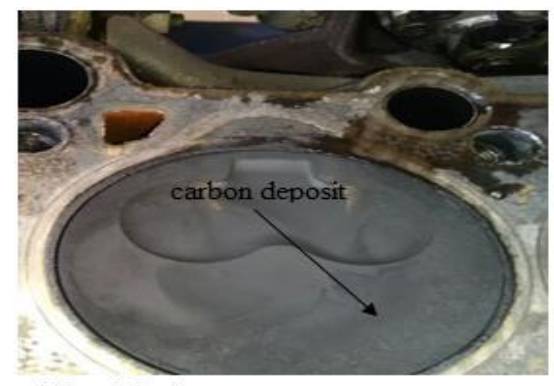

Diesel fuel

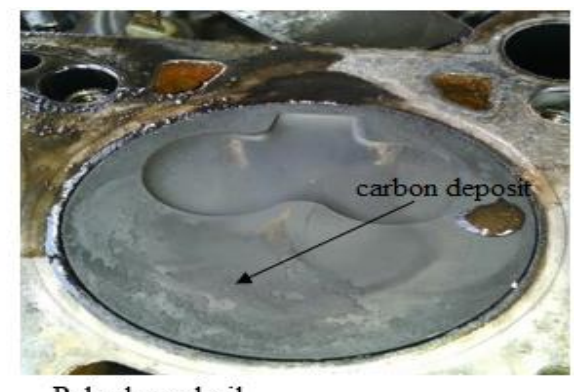

Palm kernel oil

Fig. 1: Carbon deposit on piston surfaces after the durability test

\subsection{Nozzles}

The Fuel Injection Equipment (FIE) manufacturers also accept the use of biodiesel blends up to B7 meeting EN 590:2009, provided the biodiesel meets EN14214:2009. There is thus no standard for Nozzle use beyond B7. Inspection of injection nozzles for both instances of petroleum diesel and palm kernel use showed contrasting results. There was rather carbon deposition on the nozzle tip of engine used with petroleum diesel. In contrast, less carbon deposit was found around the nozzle orifices in the palm kernel oil engine. Figure 2 and 3 shows the carbon deposit on the surface of the nozzle of both fuel cases.

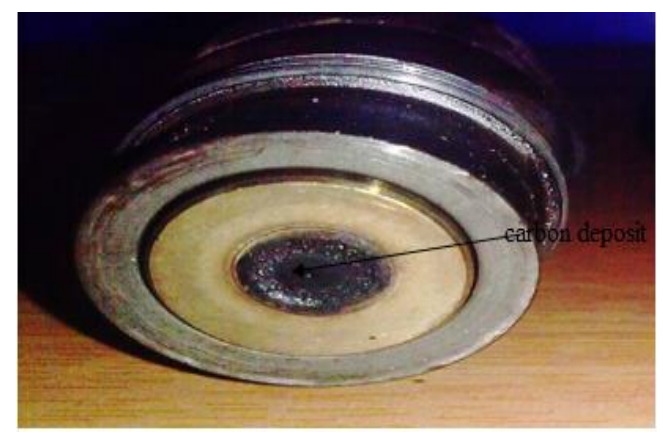

Fig. 1: Fuel injection nozzle tip after durability test with petroleum diesel 


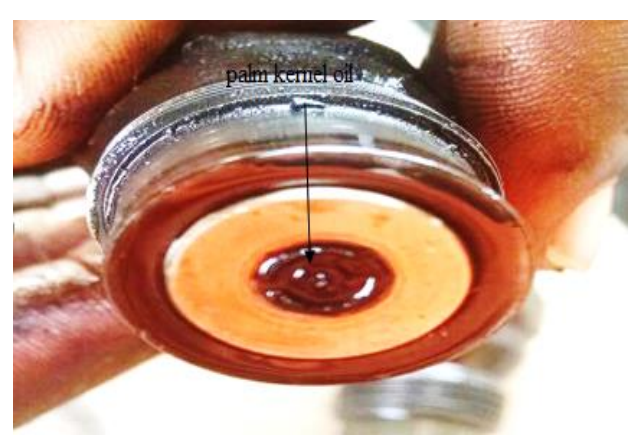

Fig. 2:Fuel injection nozzle tip

\subsection{Fuel filters}

Each of the filters used for the petroleum diesel and raw palm kernel oil run were examined after 100 hours of engine run. Figure 4 depicts condition of the unused filter before experimentation.

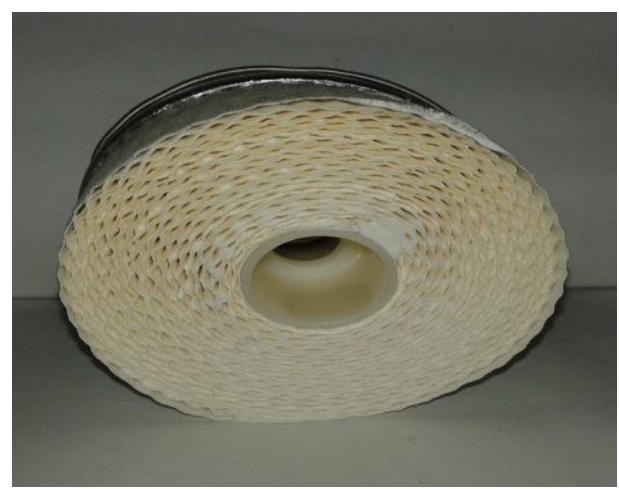

Fig.4:Unused fuel filter before durability test with palm kernel oil fuel

Figure 5 represents the condition of the fuel filter after it was run on petroleum diesel for 100 hours. It was observed that the use of petroleum diesel did not cause any significant damage to the fuel filter compared with palm kernel oil.

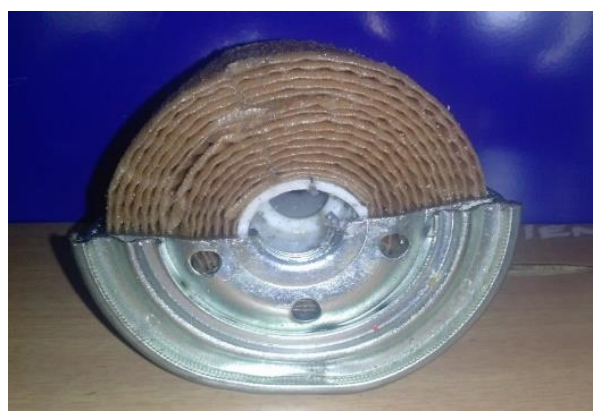

Fig.5:Fuel filter after durability test with petroleum diesel
After the durability test with the palm kernel oil fuel as shown in figure 6, it was observed that the fuel filter was plugged with oil due to its high viscosity. In addition, there were some impurities other than oil found on the filter indicating the palm kernel oil might not have been well prepared.

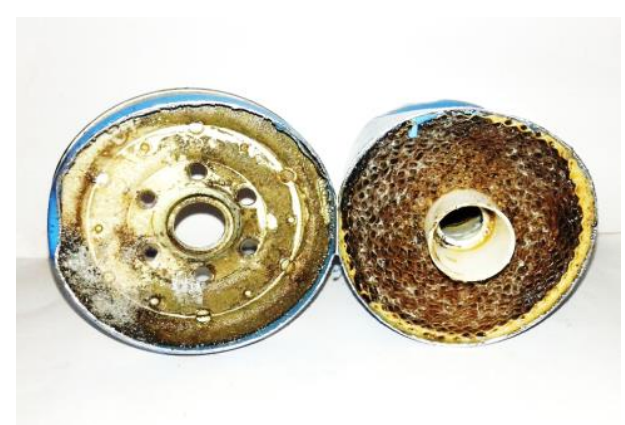

Fig. 6: Plugged fuel filter split after durability test with palm kernel oil fuel

\subsection{Fuel pipes}

It was observed that after the durability test, the petroleum diesel made no serious corrosion to the fuel pipe. There were no breaks, leakages or deformation on the rubber hose and also did not cause the fuel hoses hardening or broken. As compared with that of the engine run with palm kernel oil fuel, it was observed that the fuel pipe got plugged with the straight vegetable oil used as fuel due to high viscosity.

\subsection{Oil analysis}

Lubrication oil analysis is an important factor in determining material compatibility issues with alternative fuel engines. The main objective of crankcase lubrication is to reduce metal to metal contact and wear (Basinger, Reding, RodriguezSanchez, Lackner, \& Modi, 2010). Where there is wear and degradation, the wear materials are likely to be found in the engine oil and consequently the sump. By analysing the lubricating oil for metallic particles after engine run, sufficient information about wear, material degradation and engine condition can be obtained and/or predicted. Most common metallic components found in lubricating oils are Zinc $(\mathrm{Zn})$, Calcium $(\mathrm{Ca})$ and Iron $(\mathrm{Fe})$ or Aluminium (Al). 
Table 3

Engine oil results

\begin{tabular}{lccc}
\hline & $\begin{array}{l}\text { Engine Oil (SAE } \\
\text { 15W40) unused }\end{array}$ & $\begin{array}{l}\text { Engine Oil used } \\
\text { (petroleum diesel) }\end{array}$ & $\begin{array}{c}\text { Engine Oil used } \\
\text { (Palm kernel oil) }\end{array}$ \\
\hline $\mathrm{Fe}($ wt.\%) & 0.0046 & 0.0133 & 0.0115 \\
$\mathrm{Ca}($ wt.\%) & 0.2707 & 0.3901 & 0.3713 \\
$\mathrm{Zn}($ wt.\%) & 0.0846 & 0.0673 & 0.0884 \\
Viscosity (cSt.) & 13.7 & 17.8 & 16.8 \\
\hline
\end{tabular}

In Table 3, the concentration of iron found in the lubricating oil of palm kernel oil run engine was found to be 0.0115 wt. $\%$ while that found for petroleum diesel was 0.0133 wt. $\%$. There were about $14 \%$ more Iron particles found in petroleum diesel lubricating oil compared with palm kernel oil run lubricating oil after 100 hours of engine ran. This means that as far as iron wears are concerned palm kernel oil is a better option to petroleum diesel. Debris of iron wear originate from piston, piston rings, cylinder head, valves, gears, shafts, crankshaft and rust. The lower wear rate in the vegetable oil is due to the presence of its free fatty acids. It has widely been reported that free fatty acids, fatty acid methyl esters and monoglycerides improve lubricity (Haseeb, Masjuki, Ann, \& Fazal, 2010). Lubrication oil is well engineered so us to sustain high pressure and viscosity variation. To accomplish this, a high set of additives call additive pack is added to a lubricating oil during preparation to enhance quality. Detergents such as calcium are included in the additive pack. In addition, anti-wear chemicals such as Zinc is included in the additive pack. It can be noticed in the case of calcium detergent concentration that it was higher for both fuels than the original engine oil value of $0.2707 \mathrm{wt} . \%$. This is because when the light ends of the engine oil vapourises, the additives do not. While topping up the oil, the concentration of the additives thus increase more than the original additive value. The value of Calcium measure from engine oil from palm kernel oil was measure as $0.3713 \mathrm{wt} . \%$ while that run on petroleum diesel was 0.3901 . Calcium degradation from engine oil used on palm kernel oil engine is thus much higher than that for petroleum diesel. Where anti-wear properties are concerned, lubrication oil analysed for palm kernel oil run engine were found to be in better condition than petroleum diesel run engine. This can be seen from the Zinc concentration result of 0.0673 wt. $\%$ for petroleum diesel and 0.0884 wt.\% for palm kernel oil. The Zinc concentration of the palm kernel oil lubrication oil remained higher. This is possibly because of the already high lubricity of palm kernel oil fuel.

\subsection{Viscosity analysis}

Viscosity is a good factor in determining lubrication oil dilution. Once the lubricating oil's viscosity is reduced after engine run, it indicates deterioration of polymer additives that have been added to the lubricant. Lubrication oil used with palm kernel oil engine was found to be $16.8 \mathrm{cSt}$ while that of petroleum diesel was found to be $17.8 \mathrm{cSt}$ compared with the original lubrication oil value of $13.7 \mathrm{cSt}$. This implies there was less dilution when palm kernel oil was used. However, it was observed during engine ran of the palm kernel oil that some of the lubrication oil were noticeable in the exhaust manifold. This was not the case for petroleum diesel engine ran. Vegetable oils are widely known to have much higher boiling points compared with petroleum diesel. In this case, because palm kernel oil has a high flash point of $312{ }^{\circ} \mathrm{C}$ compared with $90{ }^{\circ} \mathrm{C}$ for petroleum diesel. In reality, during engine operation the palm kernel oil remained more in a liquid form on the cylinder wall through the bypass rings in to the crankcase causing oil dilution (Dunn, 2009). But due to the lower flashpoint of petroleum diesel, it vapourized more easily and readily moves into the ventilation system unlike palm kernel oil.

\subsection{Cost analysis of petroleum diesel and alternatives}

The data obtained so far shows biodiesel and raw vegetable oil have similar characteristics as petroleum diesel and are viable alternatives. However it will be cost effective to know the cheapest alternative among the feedstocks available in Ghana. The cost 
analysis follows a procedure to determine a unit cost

per gallon of biodiesel.

Table 4

Biodiesel production cost

\begin{tabular}{|c|c|c|c|c|c|}
\hline Variable Costs & Bulk Cost & Cost Per Unit & $\begin{array}{l}\text { Used Per } \\
\text { Batch }\end{array}$ & Per Batch & Per Gallon \\
\hline $\begin{array}{l}\text { Methanol (per } \\
\text { gallon) }\end{array}$ & $\begin{array}{l}\$ 192.50 / 55 \\
\text { gallon }\end{array}$ & $\$ 3.5$ & 8 & $\$ 28.00$ & $\$ 0.70$ \\
\hline $\begin{array}{l}\text { Catalyst }(\mathrm{KOH}) \\
\text { (per gram) }\end{array}$ & $\begin{array}{l}\$ 65 / 50 \# \text { bag } \\
(22,727 \text { grams })\end{array}$ & $\$ 0.00296$ & 1890 & $\$ 5.59$ & $\$ 0.14$ \\
\hline $\begin{array}{l}\text { Electricity (per } \\
\text { Kilowatt Hours) }\end{array}$ & $\begin{array}{l}25 \mathrm{kWh} @ \\
\$ 0.10 / \mathrm{kWh}\end{array}$ & $\$ 0.1$ & 25 & $\$ 2.50$ & $\$ 0.06$ \\
\hline $\begin{array}{l}\text { Sulphuric } \\
\text { Acid(per } \\
\text { millimetres) }\end{array}$ & $\begin{array}{l}\$ 33.18 / 2500 \\
\mathrm{~mL}\end{array}$ & $\$ 0.0130$ & 150 & $\$ 1.95$ & $\$ 0.05$ \\
\hline $\begin{array}{l}\text { Water (per } \\
\text { gallon) }\end{array}$ & $\$ 0.01 / \mathrm{gal}$ & $\$ 0.010$ & 40 & $\$ 0.40$ & $\$ 0.01$ \\
\hline Total & & & & $\$ 38.44$ & $\$ 0.96$ \\
\hline
\end{tabular}

Variable costs of each of the factors that affect biodiesel production is as shown in Table 4. On the average the total cost involved in producing a gallon of biodiesel if a biodiesel reactor is to be used will amount to $\$ 0.96$ per gallon. Table 5 shows the overall cost of production of one gallon of biodiesel from four different feedstocks. The highest biodiesel price estimation was obtained for coconut oil biodiesel with the lowest for palm oil biodiesel followed by palm kernel oil biodiesel.

Table 5

Biodiesel production total cost

\begin{tabular}{llcc}
\hline Vegetable Oil & Cost per & $\begin{array}{l}\text { Cost of biodiesel } \\
\text { production per gallon }\end{array}$ & Cost per gallon (\$) \\
\hline Palm kernel oil & $\$ 3.17$ & $\$ 0.96$ & $\$ 4.13$ \\
Coconut oil & $\$ 4.13$ & $\$ 0.96$ & $\$ 5.09$ \\
Jatropha & $\$ 3.2$ & $\$ 0.96$ & $\$ 4.16$ \\
Palm oil & $\$ 3.16$ & $\$ 0.96$ & $\$ 4.12$ \\
\hline
\end{tabular}

Currently the local price of petroleum diesel in Ghana as at $24^{\text {th }}$ July, 2015 is $\$ 3.33$ per gallon. It is clear from Table 5 , that unless the price of petroleum diesel reaches at least $\$ 5.00$ per gallon, producing biodiesel for commercial purposes will not be viable. In terms of cost it will be more competitive to use raw vegetable oil instead of biodiesel as compared with the cost of petroleum diesel.

\section{Conclusion}

- Palm kernel oil engine run of 100 hours has been achieved with an Indirect four cylinder VW diesel engine.

- There were about $14 \%$ more Iron particles found in petroleum diesel lubricating oil compared with palm kernel oil run lubricating oil after 100 hours of engine ran. This means that as far as iron wears are concerned palm kernel oil is a better option to petroleum diesel.

- The fuel filter was plugged with oil due to its high viscosity. In addition, there were some impurities other than oil found on the filter indicating the palm kernel oil might not have been well prepared.

- There was less engine oil dilution when palm kernel oil was run. However, it was observed during engine ran of the palm kernel oil that some of the lubrication oil were noticeable in the exhaust manifold. 
- In terms of cost, raw vegetable oils were found to be cheaper and more economical in use compared with petroleum diesel and biodiesel.

It is recommended that the high viscosity of the palm kernel oil will make it difficult to use during cold start conditions. It is also recommended that a heating system be installed on the engine that will utilize exhaust gasses to heat the fuel before use. For long term use it is recommended that materials such as Teflon, Viton, fluorinated plastics, and Nylon, compatible with vegetable oil use be considered for fabrication of fuel line materials. Due to the continuous plugging of the filter during use, it is recommended that servicing of engine fuelled with palm kernel oil be done twice as much as for a conventional petroleum diesel engine.

\section{References}

Agarwal, A. K. (2007). Biofuels (alcohols and biodiesel) applications as fuels for internal combustion engines. Progress in Energy and Combustion Science, 33(3), 233-271. doi: http://dx.doi.org/10.1016/j.pecs.2006.08.0 03

Aliyu, B., Shitanda, D., Walker, S., Agnew, B., Masheiti, S., \& Atan, R. (2011). Performance and exhaust emissions of a diesel engine fuelled with Croton megalocarpus (musine) methyl ester. Applied Thermal Engineering, 31(1), 36-41. doi: http://dx.doi.org/10.1016/j.applthermalen g.2010.07.034

Basinger, M., Reding, T., Rodriguez-Sanchez, F., Lackner, K., \& Modi, V. (2010). Durability testing modified compression ignition engines fueled with straight plant oil. Energy, 35(8), 3204-3220.

Blin, J., Brunschwig, C., Chapuis, A., Changotade, O., Sidibe, S., Noumi, E., \& Girard, P. (2013). Characteristics of vegetable oils for use as fuel in stationary diesel engines-Towards specifications for a standard in West Africa. Renewable and Sustainable Energy Reviews, 22, 580-597.

Bohl, T., Tian, G., Zeng, W., He, X., \& Roskilly, A. (2014). Optical Investigation on Diesel Engine Fuelled by Vegetable Oils. Energy Procedia, 61, 670-674.

Dunn, R. O. (2009). Effects of minor constituents on cold flow properties and performance of biodiesel. Progress in Energy and Combustion Science, 35(6), 481-489.
Escobar, J. C., Lora, E. S., Venturini, O. J., Yáñez, E. E., Castillo, E. F., \& Almazan, O. (2009). Biofuels: Environment, technology and food security. Renewable and Sustainable Energy Reviews, 13(6-7), 1275-1287. doi: http://dx.doi.org/10.1016/j.rser.2008.08.01 4

Gopal, K. N., \& Raj, R. T. K. (2016). Effect of pongamia oil methyl ester-diesel blend on lubricating oil degradation of di compression ignition engine. Fuel, 165, 105114.

Haseeb, A. S. M. A., Masjuki, H. H., Ann, L. J., \& Fazal, M. A. (2010). Corrosion characteristics of copper and leaded bronze in palm biodiesel. Fuel Processing Technology, 91(3), 329-334. doi: http://dx.doi.org/10.1016/j.fuproc.2009.11 .004

Hazrat, M., Rasul, M., \& Khan, M. (2015). Lubricity Improvement of the Ultra-low Sulfur Diesel Fuel with the Biodiesel. Energy Procedia, 75, 111-117.

Hellier, P., Ladommatos, N., \& Yusaf, T. (2015). The influence of straight vegetable oil fatty acid composition on compression ignition combustion and emissions. Fuel, 143, 131 143.

Hossain, A. K., \& Davies, P. A. (2010). Plant oils as fuels for compression ignition engines: a technical review and life-cycle analysis. Renewable Energy, 35(1), 1-13.

IEO. (2007). International Energy Outlook 2007. Washington: U.S. Department of Energy Retrieved from http://www.eia.doe.gov/oiaf/ieo/pdf/048 4(2007).pdf.

IEO. (2014). International Energy Outlook 2014. Washington: Retrieved from www.eia.gov/forecasts/ieo/pdf/0484(2014) .pdf.

Innovam. (2007). Diesel Fuel Systems

Knothe, G., Krahl, J., \& Van Gerpen, J. (2015). The biodiesel handbook: Elsevier.

Mofijur, M., Masjuki, H., Kalam, M., Atabani, A., Shahabuddin, M., Palash, S., \& Hazrat, M. (2013). Effect of biodiesel from various feedstocks on combustion characteristics, engine durability and materials compatibility: A review. Renewable and Sustainable Energy Reviews, 28, 441-455.

Wander, P. R., Altafini, C. R., Colombo, A. L., \& Perera, S. C. (2011). Durability studies of mono-cylinder compression ignition 
engines operating with diesel, soy and castor oil methyl esters. Energy, 36(6), 3917-3923.

doi:

http://dx.doi.org/10.1016/j.energy.2010.10 .037

Wander, P. R., Altafini, C. R., Moresco, A. L., Colombo, A. L., \& Lusa, D. (2011). Performance analysis of a mono-cylinder diesel engine using soy straight vegetable oil as fuel with varying temperature and injection angle. Biomass and Bioenergy, 35(9), 3995-4000. 